\title{
Adult Learning Theories and their Role in Instructional Design, Curriculum Development and Educational Technology
}

\author{
QURATULAIN \\ Department of Education, Alhamd Islamic University, Islamabad, \\ PAKISTAN. \\ IFFAT BASIT \\ Department of Education, Alhamd Islamic University, Islamabad, \\ PAKISTAN. \\ KHUDA BAKHSH \\ Department of Education, Government College University, Faisalabad, \\ PAKISTAN. \\ MUHAMMAD HAFEEZ \\ Research Scholar, Allama Iqbal Open University, Islamabad, \\ PAKISTAN.
}

\begin{abstract}
Modern lifelong learning, and especially when it involves technical issues, is absolutely necessary in any modern form of development and environmental protection. States and societies need to constantly focus on lifelong learning because it is the best investment that pays off in the short and long term. A critical stage was emergence of adult learning theories in learning process. Cognitivism, constructivism, Behaviorism and connectivism have been broadly applied in educational learning process to enhance the educational learning system according to the students capabilities and requirements. This study analyzed four adult learning theories namely constructivism, behaviorism, connectivism and cognitivism and their importance in lesson design, curriculum development and educational technology. The current review study's findings revealed that cognitivism, constructivism and behaviourism are foundations for syllabus development, instruction design and technology development. To incorporate technology into the learning process, the connectivism learning theory connects the learning theories of cognitivism, behaviourism and constructivism. The difficulties in putting learning theories into practice, as well as potential solutions, are addressed in this article.
\end{abstract}

Key Words: Environment, Development, Challenges, Cognitive Skills, Instructors, Learning Strategies, Technological Tools

Received: April 12, 2021. Revised: October 2, 2021. Accepted: October 22, 2021. Published: November 11, 2021.

\section{Introduction}

Learning is a basic requirement of humankind and an important part for the development of educational system of a state [1]. Various adult learning theories have been presented in different studies to improve the teachinglearning and psychological process [2-3]. The purposes of presenting learning theories were to recognize and advance the educational learning process according to the learner's skills and mental ability [4]. The learning theory considers that how an instructor or coach influences on the behaviour of learners in a learning process. The educators play a vital role in educational learning systems by generating the proper environment [5]. The researchers [6] counseled that running with the novices in numerous conditions, the teachers practice conceptual understanding to reap higher achievements. Yanchar et al [7] reported in a study that getting to know about adult learning theories are a method of verified educational strategies. Yilmaz [8] projected in a research study that getting to know about adult learning theories offer a fundamental 
stone for development of coaching as those spotlight the numerous statistics of getting to know educational learning system. Adult Learning theories are full-size in studies paintings as they provide steering and offer a fundamental structural context. Additionally, the academics need to be privy to getting to know theories to use the essential getting to know about principles of learning [9]. The adult learning theories are reassets of instructions to boom efficiency of educational system. The significance of adult learning theories in curriculum development, educational layout and academic era has been demonstrated in many studies [10-11]. The adult learning theories play a key role in the development and implementation of curriculum. Various adult learning theories have been developed to provide guidance for curriculum development and improvement by indicating how an individual learns and retains knowledge under the principles of these theories. Hence, the learning theories provide a basic framework to make the decisions for the development and implementation of curriculum. It is also very important to assess that how various adult learning theories provide framework to formulate the curriculum. The wanted results can be attained if curriculum established and executed on the basis of relevant learning theory [12]. The adult learning theories are vital for improvement of academic approaches. Many research studies were carried out at the utility of studying theories to increase the academic strategies and strategies. In the existing era, studying theories are being advanced into the academic layout theories to enhance the studying method in line with the brand-new want of society and make it comprehensible New academic methods were evolved in line with the wishes of the numerous instructional institutions, studying environments, mind technology and different applicable functions with the aid of using the usage of studying theories standards and methods [13].

The adult learning theories specifically constructivism and connectivism play an essential function for the improvement of tutorial era. The constructivism and connectivism theories are operating with era to enhance the studying technique. The constructivism concept is base in geometry for the improvement of curriculum and eraprimarily based totally studying. The connectivism concept offers a theoretical base for studying technique on this age of era. It highlights how era may be used withinside the studying system. The behaviorism concept of studying is likewise very critical for the improvement of era-primarily based totally studying technique [14].

\subsection{Purpose of the Study}

The adult learning theories furnished the idea to create the mastering surroundings consistent with the learner's surroundings as concluded in numerous research including [15-16]. By understanding the significance of adult learning theories, the cause of cutting-edge have a look at changed into to speak about the function of adult learning theories Instructional Design, Curriculum Development and Educational Technology.

\section{Review of Literature}

The numerous adult learning theories have been developed to define and implement the learning environment according the situations and learner's requirements. The classroom environment and learning strategy are two key elements for the desired achievements and outcomes. The learning theories provide the guidance that how to implement the learning process to keep the classroom environment according to the requirement of the learners. Many studies including [17] have been conducted on the implementation of various adult learning theories to the classroom environments.

\subsection{Theoretical Background of Adult Learning Theories}

The theoretical framework of various learning theories are discussed in the following lines:

\subsubsection{Behaviorism Adult Learning Theory}

The Behaviorism theory of learning is based on visible changes in learner's behaviour. This theory mainly focuses on adopting new 
behavioral outline repeatedly until it becomes habit. The behaviorism adult learning theory makes a specialty of the manner of apparent behaviors which may be measured and discovered. This getting to know idea knows that thoughts is similar to Black box in which replies to incentives cab be judged and discovered quantitively through disregarding notion manner going on withinside the thoughts [18]. Behaviorism adult learning theory is a main educational adult learning theory. This adult learning theory is primarily created totally on two characteristics named outside incentives and its replies. The followers of Behaviorism adult theory consider that studying is powerful handiest while scholars exhibit it with incentives and favored reaction via way of means of conditioning. Learning is the alternate in behaviour of the novices and behavior is maintained via way of means of reinforcement [19].

\subsubsection{Behaviorism Adult Learning Theory Implications in Classroom Context}

The behaviorism adult learning theory may be carried out honestly in classroom context because it bases on observable behavior. Two strategies, bad and fine may be powerful for gaining knowledge of withinside the classroom context. These strategies are known as reinforcement strategies. When an instructor offers punishment and praise withinside the study room, they may be simply following behaviorism gaining knowledge of principle. A generally false impression exists withinside the society that bad reinforcement suggests punishment; however, in behaviorism adult learning theory, bad reinforcement method the eradication of bad stimulus to enhance the preferred behavior [20]. Implication of behaviorism adult learning theory in classroom context is shown in Table 1.

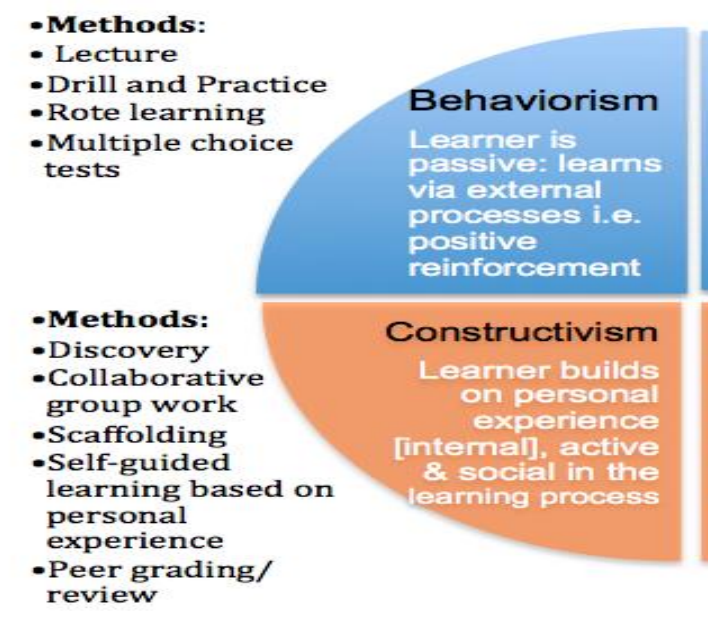

- Lecture

- Drill and Practice
-Methods:

- Lecture

-Visual tools:

mind maps,

charts etc to

facilitate

memorization

for learning

- Multiple choice \&

essay assessment

- Methods:

-Self-directed quest for

content

- Sharing of content

sources

-Spontaneous learning

groups

- Creates knowledge

collaboratively

Figure.1: Basic Concept, Methods of Application of Adult Learning Theories 
Table.1: Implication of adult learning theory in Classroom Context

\begin{tabular}{|c|c|c|c|}
\hline Level & & Reinforcement & Punishment \\
\hline Positive & & $\begin{array}{l}\text { Give students good things to } \\
\text { improve learning behavior }\end{array}$ & $\begin{array}{l}\text { Awarding something to minimize } \\
\text { bad learning behavior }\end{array}$ \\
\hline Negative & $\begin{array}{l}\text { To enhance the learning behavior, } \\
\text { remove something which is bad }\end{array}$ & $\begin{array}{l}\text { Conducting something good to } \\
\text { minimize the bad learning behavior }\end{array}$ & \\
\hline
\end{tabular}
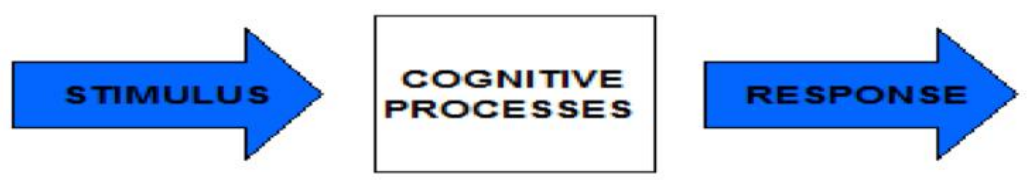

Figure.2: Learning Process in Cognitive Adult Learning Theory

Table.2: Constructivism Adult Learning Theory Features

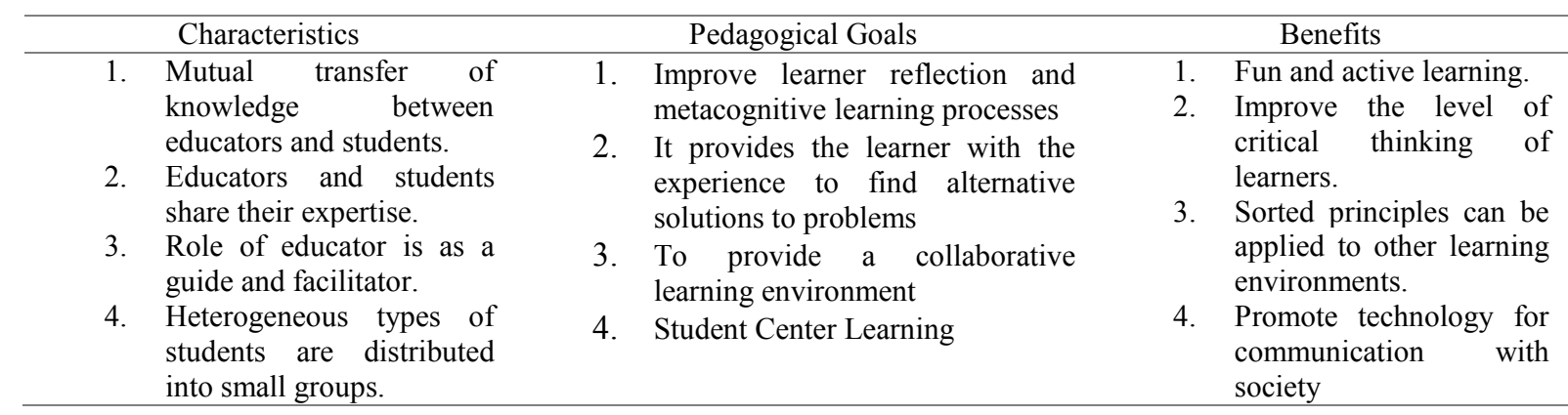




\subsection{Cognitivism Adult Learning Theory}

Cognitive adult learning theory emphasizes on mental development, the process of storing and retrieving information. Kirschner et al [21] pointed out in a research study that cognitiveists believe that learning process is an interior and positive psychological process, which grows inside students, improves their mental abilities and improves the ability of the learning process. Participatory teaching plans are designed to attract students and increase their active participation. Cognitiveists emphasize that learning activities should allow students to dynamically participate in learning process by constructing their own actions and targets. It also focuses on the cognitive theory of learning, which states what information students already know and what they must acquire to do something. In cognitive learning theory, mostly emphasizes on getting, processing and assimilating the information [22]. The learning procedure in cognitive adult learning theory is revealed in Figure 2.

Mugisha \& Mugimu [23] pointed in a research that the cognitive adult learning theory describes learning process that connects previously acquired knowledge and experience with new knowledge through dialogue, interaction, and collaboration. In the cognitive learning theory, theoretical learning happens rather than remembering knowledge. In another research Schunk [24] proposed that the information attained in cognitive adult learning theory is the consequence of mental development activity, involving learners' own internal coding and organization. Think that students actively participate in teaching and learning process. Cognitive adult learning theory is used to formulate of classroom teaching plans to help students develop higherlevel critical and communication thinking skills. This adult learning theory emphases on unobservable activities within the head.

\subsection{Constructivism Adult Learning Theory}

Constructivist adult learning theory involves knowledge creation through social interaction and spiritual effort. Jia [25] referred in a research in constructivist adult learning theory that declared that knowledge occurs in human psyche and can be varying with realism in real world. The students generate their own observations of the spiritual model in order to duplicate new information and set their own interpretation of reality in the real world. Duane \& Satre [26] stated that constructivist adult learning theory is built on thought, scientific information and procedures for learners to learn. Students learn by creating their own facts and understanding through various experiences. Learners need to be aware of their previous knowledge as they come into contact with new experiences. Learners accept or reject new experiences. In some problems, learners also play a dynamic role in creating their own awareness and facts. To resolve real life problems, student asks, evaluates and navigates what the student already identifies. Constructivist adult learning theory is connected to other disciplines such as psychology, education, sociology and philosophy. This theory plays a vital role in teaching and learning and teacher skilled development. The key idea of constructivist adult learning theory is that learning is a productive process in which a learner generates new facts based on previous knowledge. The dynamic learning arises from constructivism adult learning theory is more dynamic than submissive [27]. Zhenping et al [28] pointed in a research that constructivism adult learning theory is a philosophical process that increases the conceptual and logical growth of the learners. In another study Aljohani [28] found that in order to increase the learning process in constructivism adult learning theory, it is compulsory to produce a useful learning atmosphere to describe learning resources before the students. The most important objective of constructivism adult learning theory is to offer students a dynamic learning development. Some important features of constructivism adult learning theory are shown in Table 2 .

\subsection{Connectivism Adult Learning Theory}

Connectivism learning theory explains that learners learn in the technology environment with regular information. The central phenomena behind the connection of the connection theory is that the knowledge is accelerated and dynamic. This adult theory 
connects that information such as a network, as the network structure is included and powerful [29]. There are new links or recognized samples of existing networks in the associated theory for adults. Since knowledge networks are so chaotic and active, learning is considered a continuous procedure to accept new formulas. Planning is a metacognitive procedure in which a student calculates and rearranges the nodes of the environment and selects the remaining nodes, with the exception of some. Students choose nodes based on criteria such as individual interests and abilities, resource suitability, and resource viability [30]. During the cognitive learning phase, students interact with designated notes to search for the knowledge they need. Finally, the evaluation phase provides steps for the designated node question [31]. The connectivism adult learning theory shows that the stages of information development begin with individual knowledge by integrating knowledge through planned connections into the network. The teaching learning strategy is based on the learner's knowledge. The connectivism adult learning theory to the educational learning process through the interaction of educational networks improves cognitive abilities as well as learners' social, cultural and stimulating abilities [32].

\subsection{Role of Adult Learning Theories in Curriculum Development (CD)}

The adult learning theories are very vital for the development and implementation of curriculum. The learning theories challenge to define that how an individual learns and maintain any delivered information by applying learning principles. Various learning theories offer altering descriptions about learning process and also provide the link between what and how the learners learned under different conditions. So, the learning theories provide a basic framework to design the curriculum [33]. Actually, learning requirements are to transfer the information and skills from the intstrcutors to the learners in the classroom to apply the learned skills for the solution's real-life problems. Therefore, it is very significant to provide students with various openings to learn the skills and apply them in real life problems. Learning theory is built on approaches and values that can offer guidelines for an active teaching and learning process and allow deep learning [34]. According to Swim [35] learners' attitudes and emotions should be kept in mind when developing a curriculum after performing various curriculum activities under various conditions and situations. According to activist learning theory, learning is a reaction to a learner's stimulus. If the curriculum is developed in response to the learner's stimulus, it will generate positive enhancements for the learner and remove the negative enhancements from the learner objectives. The course content includes the greatest activities associated with positive reinforcement to achieve goals and achievements. According to a research conducted by Dietzen [36] schools are the places for the development of cognitive abilities in the learners. The cognitivism learning theory has great importance in the development of curriculum as it deals with the cognitive skills of the learners. During the curriculum development, all the factors of cognitivism learning theory must be kept in mind. The curriculam must be designed in such a way that it reflects all the factors affecting the students and the measures to pact with these issues persuading on students' working abilities [37]. A research conducted by Begg [38] showed that in constructivist adult learning theory, students build their own facts by dynamically participating in learning. The curriculum should be productive so that students can acquire knowledge constructively from it. Productive knowledge founded on students' opinions and concepts must be part of curriculum in order to implement the curriculum in to solve complex issues and problems. Rank [39] concluded in a research study that today, learners' cognitive needs have changed. Traditional learning methods lack the ability to generate enough cognitive learning capacity to compete with the current era of conceptual learning. Thus, when building a curriculum, it is essential that learners mix information technology into the curriculum development. 


\subsection{Instructional Design and role of Adult Learning Theories}

Behaviorist adult learning theory focuses on individual student behavior in the learning process. Each individual may respond differently to learning stimuli. Therefore, teachers should design instructions in such a way that every student acts in a positive way during the learning process for this purpose the instructors should remove the bad reinforcement in the learners [40]. The cognitivism learning theory states about the cognitive (mental) abilities and the development of that cognitive abilities of the learners. The cognitive abilities are very important for the development of communication and critical thinking skills. Teachers 'teaching strategies play a fundamental role in the development of students' cognitive abilities. Teachers must design courses in such a way that they can develop students' cognitive skills. Teaching strategies should be based on the cognitive level of the students [41]. The constructivism adult learning theory discusses the active and cooperative learning process between the learners. The learners learn more by doing activities in the classroom. The cooperative learning improves the cognitive skills of the learners and compels the learners to dynamically participate in learning. Therefore, teachers need to advance instructions based on constructivist adult learning theories, including activity-based learning to improve learners' learning abilities [42].

\subsection{Educational Technology and Role of Adult Learning Theories}

Adult learning theories (activist, cognitivist and constructivist) are foundation of connected adult learning theory. Traditional learning theories (Activist, Cognitivist and Constructivist) combine these theories and pay attention to connections, providing a platform for constructing new learning theories called adult learning theories. Connectivism Adult learning theory is the further development in traditional learning theory by mixing information technology into learning process. Connectivism adult theory connects all traditional theories by applying information technology in learning process [43].

\section{Challenges for Implications of Learning Theories in Classroom Context}

The instructors face many challenges for implementing learning theories in the learning process of classroom context. According to Anderson [44], some major challenges are (i) The instructors may have to change their teaching methods and styles which is very difficult task for an instructor (ii) There may be needed to change the environmental conditions according to the learning theories that becomes very difficult at some places (iii) A large amount of funds required to impose the connectivism leaning theory (iv) A strict and friendly environment is needed to implement the learning theories into curriculam which is impossible in some scenario.

\section{Discussion}

The development of adult learning theories have been a great achievement in learning and teaching process. Cognitivism, Constructivism, Behaviorism and Connectivism are four main learning theories that are widely used in the learning process, developing learners' cognitive abilities and nurturing skilled workers according to the needs of currant age [45-47]. Behaviorist adult learning theory discourses learners behaviors in response to stimuli. This theory addresses the learner's inner feelings and inner emotional responses. Cognitive adult learning theory contracts with cognitive skills of learners. The ability of students to ponder and generate for themselves is said to be learner cognitive ability [48]. Cognitive learning theory is extensively applied in research to emphasize its status in development of learners' critical and creative thinking skills [49-50]. Constructive adult learning theory is concerned with development of the students own facts based on perceptions. This adult theory addresses the critical and creative thinking skills of learners [51]. Some other 
relvant studies can be found in [52], [53] and [54]. Finally, connectivist adult learning theory links all learning theories (cognitivism, behaviorism and constructivism) with computational tools to generate a valuable learning environment for students. Connectivity adult theory deals with the linking between traditional and current digital learning tools.

\section{Conclusion}

A retrospective review of literature on the role of numerous adult learning theories in instructional design, educational technology and curriculum development has been discussed. The review of literature showed that learning theories play a dynamic role in teaching and learning process. Usage of learning theories of cognitivism, behaviorism, constructivism and connectionism in learning enhanced the students' cognition and creative thinking skills. All of these adult learning theories are significant in instructional design, curriculum development and technical execution of learning process. Modern lifelong learning, and especially when it involves technical issues, is absolutely necessary in any modern form of development and environmental protection. States and societies need to constantly focus on lifelong learning because it is the best investment that pays off in the short and long term.

\section{References}

[1] Hafeez M, Kazmi QA, Tahira F, Hussain MZ, Ahmad S, Yasmeen A, Iqbal J, Saqi MI. Impact of school enrolment size on student's achievements. Indonesian Journal of Basic Education. Vol.3, no.1, pp.1721, 2020.

[2] Kamel-ElSayed, S. and Loftus, S. Using and combining learning theories in medical education. Medical Science Educator, Vol.28 No. 1, pp.255-258, 2018.

[3] Szabo, Claudia, Nickolas Falkner, Andrew Petersen, Heather Bort, Cornelia Connolly, Kathryn Cunningham, Peter Donaldson, Arto Hellas, James Robinson, and Judy Sheard. "A Periodic Table of
Computing Education Learning Theories." In Proceedings of the 2019 ACM Conference on Innovation and Technology in Computer Science Education, pp. 269-270. 2019.

[4] Campbell, Anita, Tracy Craig, and Brandon Collier-Reed. "A framework for using learning theories to inform 'growth mindset' activities." International Journal of Mathematical Education in Science and Technology, Vol.51, no. 1, pp. 26-43, 2020.

[5] Fayolle, Alain, and Benoît Gailly. From craft to science: Teaching models and learning processes in entrepreneurship education. No. hal-02313007. 2012.

[6] Arghode, V. and Wang, J. "Exploring trainers' engaging instructional practices: a collective case study", European Journal of Training and Development, Vol. 40 No. 2, pp. 111-127, 2016.

[7] Yanchar, Stephen C., Joseph B. South, David D. Williams, Stephanie Allen, and Brent G. Wilson. "Struggling with theory? A qualitative investigation of conceptual tool use in instructional design." Educational Technology Research and Development, vol. 58, no. 1, pp.39-60, 2010.

[8] Yilmaz, K. "The cognitive perspective on learning: its theoretical underpinnings and implications for classroom practices", The Clearing House: A Journal of Educational Strategies, Issues and Ideas, Vol. 84 No. 5, pp. 204-212, 2011.

[9] Arghode, Vishal. "Emotional and social intelligence competence: Implications for instruction." International Journal of Pedagogies and Learning, Vol. 8, no. 2, pp.66-77, 2013.

[10] Khalil, Mohammed K., and Ihsan A. Elkhider. "Applying learning theories and instructional design models for effective instruction." Advances in physiology education, vol. 40, no. 2, pp.147-156, 2016.

[11] Budiningsih, C.A., Haryanto, $\mathrm{H}$. and Rahmadona, S. The Development of Blended Learning Theories of Learning Course for 
Educational Technology Student in FIP UNY. KnE Social Sciences, pp.170-182, 2019.

[12] Shrivastava, S.R. and Shrivastava, P.S. Employing adult learning theories in designing a module. Research and Development in Medical Education, vol. 6 no.2, pp.6465, 2017.

[13] Şanal, S.Ö., Akçay, A., Tutulmaz, M.Ç. and Erdem, M. Application of Learning Theories in Online Instructional Environments and Materials: A Study for Developing a Set of Criteria. Bartin Üniversitesi Egitim Fakültesi Dergisi, vol. 8 no.2, pp.707-732, 2019.

[14] Vanhorn, S., Ward, S.M., Weismann, K.M., Crandall, H., Reule, J. and Leonard, R. Exploring active learning theories, practices, and contexts. Communication research trends, vol. 38 no.3, pp.5-25, 2019.

[15]

Ater, I. and Landsman, V. Testing alternative learning theories: Evidence from subscription contracts. The Journal of Industrial Economics, vol.66 no.4, pp.763-815, 2018.

[16] Çeliköz, N., Erisen, Y. and Sahin, M. Cognitive Learning Theories with Emphasis on Latent Learning, Gestalt and Information Processing Theories. Online Submission, vol.9 no.3, pp.18-33, 2019.

[17] Mahmud, M.M., Yaacob, Y., Ramachandiran, C.R., Ching, W.S. and Ismail, $\mathrm{O}$. Theories into Practices: Bloom's Taxonomy, Comprehensive Learning Theories (CLT) and EAssessments, vol.2 no.2, pp.22-27, 2019.

[18] Staddon, J. Theoretical behaviorism, economic theory, and choice. History of Political Economy, vol. 48 no.suppl_1, pp.316331, 2016.

[19] Dastpak, M., Behjat, F. and Taghinezhad, A. A Comparative Study of Vygotsky's Perspectives on Child Language Development with Nativism and Behaviorism. Online Submission, vol. 5 no.2, pp.230-238, 2017.
[20] Miller, Carrie Lewis, Michael Manderfeld, and Elizabeth A. Harsma. "Learning Theories: Behaviorism." 2019.

[21] Kirschner, P.A., Park, B., Malone, S. and Jarodzka, H. Toward a cognitive theory of multimedia assessment (CTMMA). Learning, design, and technology: An international compendium of theory, research, practice, and policy, pp.1-23, 2017.

[22] Frank, M.J. and Badre, D. How cognitive theory guides neuroscience. Cognition, vol. 135, pp.14-20, 2015.

[23] Mugisha, W.R. and Mugimu, C.B., 2015. Application of learning theories in curriculum development and implementation of the MLT diploma programme in Uganda. Journal of Education, Society and Behavioural Science, pp.256-275.

[24] Schunk, Dale H. Learning theories an educational perspective sixth edition. Pearson, 2012.

[25] Jia, Q. A brief study on the implication of constructivism teaching theory on classroom teaching reform in basic education. International Education Studies, vol.3 no.2, pp.197199, 2010.

[26] Duane, B.T. and Satre, M.E. Utilizing constructivism learning theory in collaborative testing as a creative strategy to promote essential nursing skills. Nurse Education Today, vol.34 no.1, pp.31-34, 2014.

[27] Jumaat, N.F., Tasir, Z., Halim, N.D.A. and Ashari, Z.M. Projectbased learning from constructivism point of view. Advanced Science Letters, vol.23 no.8, pp.7904-7906, 2017.

[28] Xie, Z., Jin, C. and Liu, Y. Personalized knowledge recommendation model based on constructivist learning theory. Journal of computer research and development, vol.55 no.1, p.125-138, 2018.

[29] Luhamya, A., Bakkabulindi, F.E.K. and Muyinda, P.B. Integration of ICT in teaching and learning: a review of theories. Makerere Journal 
of Higher Education, vol.9 no.1, pp.21-36, 2017.

[30] Munna, A.S. and Kalam, M.A. Application of Theories, Principles and Models of Curriculum Design: A Literature Review. Online Submission, vol. 3 no 1, pp.147-153, 2021.

[31] Şahin, M. Pros and cons of connectivism as a learning theory. International Journal of Physical and Social Sciences, vol.2 no.4, pp.437-454, 2012.

[32] Rostovtseva, V.M. and Nizkodubov, G.A. Pedagogicalhermeneutic approach to the interpretation of the competence phenomenon in modern research. International Journal of Social Sciences and Humanities, vol.4 no.2, pp.57-68, 2020.

[33] Yardley, S., Teunissen, P.W. and Dornan, T. Experiential learning: transforming theory into practice. Medical teacher, vol.34 no.2, pp.161-164, 2012.

[34] Ah-Nam, L. and Osman, K. Developing 21 st century skills through a constructivist-constructionist learning environment. K-12 STEM Education, vol.3 no.2, pp.205-216, 2017.

[35] Swim, Terri Jo. Infants, Toddlers, and Caregivers: Caregiving and Responsive Curriculum Development. Cengage Learning, 2016.

[36] Dietzen, A. Knowledge Concepts in Competence-based VET Research Perspectives on Cognitivist and Social-Constructivist Approaches. In Competence-based Vocational and Professional Education (pp. 719-737). Springer, Cham, 2017.

[37] Akhigbe, T. Cognitivism and ultrasound skills in emergency medicine training: from theory to practice. International Journal of Medical Reviews, vol.5 no.2, pp.4749, 2018.

[38] Begg, A. Constructivism: An overview and some implications, 2015.

[39] Rank, P. Using connectivism theory in the classroom. NACTA
Journal, vol.62 no.1, pp.102-103, 2018.

[40] Muslimin, M.S., Nordin, N.M., Mansor, A.Z., Ismail, I.M. and Hamdan, F. Application of Learning Theories in Design and Development of the Mobile Application for Microeconomics Course. Advanced Science Letters, vol.24 no.4, pp.24752479, 2018.

[41] Cronje, J. Towards a new definition of blended learning. Electronic journal of eLearning, vol.18 no.2, pp.pp114-121, 2020.

[42] Bailey, E.K. Applying learning theories to computer technology supported instruction. In Advancing next-generation teacher education through digital tools and applications, pp. 61-81. IGI Global, 2017.

[43] Díaz Martínez, J. A., \& Hernández de Frutos, $\mathrm{T}$. Connectivism in the Network Society. The Coming of Social Capital Knowledge. Tendencias Sociales. Revista De Sociología, no.1,pp.21-37, 2018.

[44] Anderson, J.A. Challenges and Opportunities: Mixed Research for Improving Outcomes for Students with Emotional and Behavior Disabilities. Research in the Schools, vol.25 no.2, 2018.

[45] Liu, C.H. Creating competitive advantage: Linking perspectives of organization learning, innovation behavior and intellectual capital. International Journal of Hospitality Management, vol.66, pp.13-23, 2017.

[46] Seufert, T. The interplay between self-regulation in learning and cognitive load. Educational Research Review, vol.24, pp.116-129, 2018.

[47] Yoong, Y.Y., Kaur, S. and Keat, P.H. Constructivist Learning, Vocabulary Learning Strategies and Motivational Theories for English Vocabulary Acquisition Tool Using Cloud Computing. International Journal of Academic Research in 
Business and Social Sciences, vol.9 vol.13, pp.304-318, 2019.

[48] Schmidt, J. Effective Management of Creativity and Innovation in Education: Theories and Best Practices. In Handbook Of The Management Of Creativity And Innovation: Theory And Practice, pp. 117-132, 2017.

[49] Dilshad, M.N. Learning theories: Behaviorism, cognitivism, constructivism. International Education and Research Journal, vol.3 no.9, pp.64-66, 2017.

[50] Turan, Y., 2018. role of affective factors in foreign language learning. Journal of Educational \& Instructional Studies in the World, vol.8 no. 3, 2018.

[51] Fedyk, M. and $\mathrm{Xu}, \mathrm{F}$. The epistemology of rational constructivism. Review of Philosophy and Psychology, vol.9 no.2, pp.343$362,2018$.

[52] Hanna Kotina, Maryna Stepura, Viktor Fedosov, Denys Hrysohlazov, Marina Bilinets, Competitiveness of Higher Education in Ukraine and Certain European Countries: Empirical Studies on Funding and Academic Attractiveness, WSEAS Transactions on Business and Economics, pp. 849-858, Volume 17, 2020

[53] Edgardo Cayon, Juan Santiago Correa, Julio Alejandro Sarmiento, Does Quality Make a Difference for Higher Education Graduates in Colombia? Measuring Differences in Accredited and Non-accredited Institutions with Similar Financial Characteristics, WSEAS Transactions on Business and Economics, pp. 859868, Volume 17, 2020

[54] Beata Sadowska, Adam Lulek, The Importance of Environmental-forest Education in Managing Information on Natural Resources, WSEAS Transactions on Business and Economics, pp. 775-785, Volume 17, 2020

\section{Creative Commons Attribution License 4.0 (Attribution 4.0 International, CC BY 4.0)}

This article is published under the terms of the Creative Commons Attribution License 4.0

https://creativecommons.org/licenses/by/4.0/deed.en_US 